\title{
Studies on Growth, Yield and Quality of Pigeon Pea (Cajanus cajan L. millsp.) as Influenced by Different Levels of Phosphorous and Liquid Biofertilizers
}

\author{
U.K. Ade, S.A. Bhusari", S.G Mane and N.K. Kalegore \\ Agronomy section, College of Agriculture, VNMKV, Latur, India
}

*Corresponding author

\begin{tabular}{|l|}
\hline K e y w or d s \\
Rhizobium, \\
Biofertilizer, PSB, \\
Phosphorus
\end{tabular}

A B S T R A C T

A field was conducted at Experimental Farm, Agronomy Section, College of Agriculture, Latur. The experimental field was levelled and well drained. The soil was medium and black in colour with good drainage. The soil was clayey in nature and slightly alkaline (7.8) in reaction, low in nitrogen $\left(118.86 \mathrm{~kg} \mathrm{ha}^{-1}\right)$, medium in available phosphorus (17.7 $\mathrm{kg} \mathrm{ha}^{-1}$ ) and rich in available potassium485.89 kg ha ${ }^{-1}$. The environmental conditions were favorably congenial for normal growth and maturity of pigeonpea crop. The experiment was laid out in Factorial Randomized Block Design with two factors and replicated thrice. Whereas first factor comprises levels of phosphorus viz., 0 (control), 40, 50 and $60 \mathrm{~kg} \mathrm{P}$ $\mathrm{ha}^{-1}$, second factor comprises seed inoculations with biofertilizer viz. alone inoculation of Rhizobium@6 ml kg-1 seeds, alone inoculation PSB @ $6 \mathrm{ml} \mathrm{kg}^{-1}$ seeds and dual inoculation Rhizobium + PSB each of @6 ml kg-1 seeds. The experimental site having gross and net plot size was $5.4 \times 4.5 \mathrm{~m}^{2}$ and $4.2 \times 3.9 \mathrm{~m}^{2}$ respectively. The application of phosphorus@60 kg ha ${ }^{-1}$ given significantly higher growth and yield attributes, gross monetary return and net monetary return over the rest of the levels of phosphorus. Whereas NMR was remained at par with $50 \mathrm{~kg} \mathrm{P} \mathrm{ha}^{-1}$. Among three biofertilizer treatments, dual seed inoculation with Rhizobium + PSB was recorded higher growth and yield attributes, gross monetary return and net monetary return than the individual seed inoculation of Rhizobium or PSB.

\section{Introduction}

Pigeonpea (Cajanus cajan L. Millsp.) is one of the major grain legume (pulse) crop of the tropics and subtropics. It is grown on mountain slopes to reduce soil erosion. Protein content in pigeon pea seeds compares well with that of other important grain legumes. Pigeonpea is commonly known in India as redgram or arhar or tur. It is a tropical crop grown in India, predominantly, during the kharif season both as sole crop and as intercrop, though found in wide range of agroecological situations. Its deep rooting and drought tolerant character make it as successful crop in areas of low and uncertain rainfall. Being a leguminous plant is capable of fixing atmospheric nitrogen and thereby restores nitrogen in the soil. Its deep root system helps in extracting nutrient and moisture from deeper soil layers, thus making it suitable for rainfed condition. 
India accounts for 90 percent of pigeonpea areas and production of the world, which is grown in an area of 3.90 million hectare with production 3.17 million tonnes and productivity of $817 \mathrm{~kg} \mathrm{ha}^{-1}$ (Anon., 2015-16). In Maharashtra it was grown on 10.37 lakh hectare with production of 66.1 lakh tonnes and productivity of $637 \mathrm{~kg} \mathrm{ha}^{-1}$ during 2014 (Anon., 2015-16). It is mainly grown in states of Maharashtra, Karnataka, Andhra Pradesh, Uttar Pradesh, Gujarat, Madhya Pradesh and these states constitutes 90 per cent of the area (Anon., 2015-16). In Marathwada region major pigeon pea growing districts are Aurangabad, Jalna, Beed, Parbhani, Osmanabad, Latur, Nanded and Hingoli.

Phosphorus is a key element involved in various function in growth and metabolism of pulses. It is frequently a major limiting nutrient for plant growth in most Indian soils. Phosphorus solubilising bacteria (PSB) can play an important role in increasing phosphorus availability by solubilising the $\mathrm{P}$ and supplying it to plants in a more available form (Khan et al., 2007). Inoculants of efficient nitrogen fixing solubilizing bacteria (PSB) which have established their capability in augmenting the productivity of pulses may fulfil the nitrogen and phosphorus needs considerably. The prices of inorganic fertilizers are beyond the reach of marginal farmers. Under these circumstances the present investigation is proposed.

\section{Materials and Methods}

A field experiment was conducted on medium black soils at Agronomy Section Farm, College of Agriculture, Latur during kharif season of 2016-17. The experiment was laid out in Factorial Randomized Block Design with two factors and replicated thrice. Whereas first factor comprises levels of phosphorus viz. 0 (control), 40, 50 and $60 \mathrm{~kg} \mathrm{P}$ $\mathrm{ha}^{-1}$, second factor comprises seed inoculations with biofertilizer viz. alone inoculation of Rhizobium @ $6 \mathrm{ml} \mathrm{kg}^{-1}$ seeds, alone inoculation PSB @ $6 \mathrm{ml} \mathrm{kg}^{-1}$ seeds and dual inoculation Rhizobium + PSB each of @ $6 \mathrm{ml} \mathrm{kg}^{-1}$ seeds. The experimental site having gross and net plot size was $5.4 \times 4.5 \mathrm{~m} 2$ and 4.2 x $3.9 \mathrm{~m} 2$ respectively. The recommended dose of fertilizer was applied at time sowing (25:50:00 NPK kg ha ${ }^{-1}$ where $\mathrm{P}$ applied as per treatments). The sowing was done on 22 nd June 2016 by dibbling and harvested on $3^{\text {rd }}$ January 2017. All the cultural practices were followed by as per package of practices.

\section{Results and Discussion}

\section{Effect of phosphorus on growth and yield}

The maximum plant height $(173.8 \mathrm{~cm})$, number of functional leaves plant ${ }^{-1}$ (286.6), number of branches plant ${ }^{-1}$ (7.9), number of nodules (23.1) and dry matter plant ${ }^{-1}$ (188.1 gm) were recorded due to the application of 60 $\mathrm{kg} \mathrm{P} \mathrm{ha}{ }^{-1}$ and significantly superior than control but satisfactory at par with 40 and 50 $\mathrm{kg} \mathrm{P} \mathrm{ha}{ }^{-1}$. The higher number of pods plant ${ }^{-1}$ (209.3) and seed yield (2613 $\left.\mathrm{kg} \mathrm{ha}^{-1}\right)$ was obtained by the application of $60 \mathrm{~kg} \mathrm{P} \mathrm{ha}{ }^{-1}$, and remained at par with $50 \mathrm{~kg} \mathrm{P} \mathrm{ha}{ }^{-1}$. Application of $60 \mathrm{~kg} \quad \mathrm{P} \quad \mathrm{ha}^{-1}$ recorded significantly higher leaf area recorded (5.56 $\mathrm{dm}^{2}$ ) and test weight (94.4 g) over control, 40 and $50 \mathrm{~kg} \mathrm{P} \mathrm{ha}^{-1}$.

\section{Effect of bio-fertilizers on growth and yield}

Pigeon pea seed treated with liquid rhizobium culture + liquid PSB (phosphorus solubilizing bacteria) recorded significantly higher growth and yield attributes viz. number of functional leaves plant ${ }^{-1}$, number of branches plant $^{-1}$, number of nodules, dry matter plant ${ }^{-1}$, number of pods plant ${ }^{-1}$, seed yield and test weight, than alone application of rhizobium and PSB culture while it was found comparable with PSB in respect of plant height (Table 1). 
Table.1 Effect of different levels of phosphorus and various liquid bio-fertilizers on growth and yield of pigeon pea

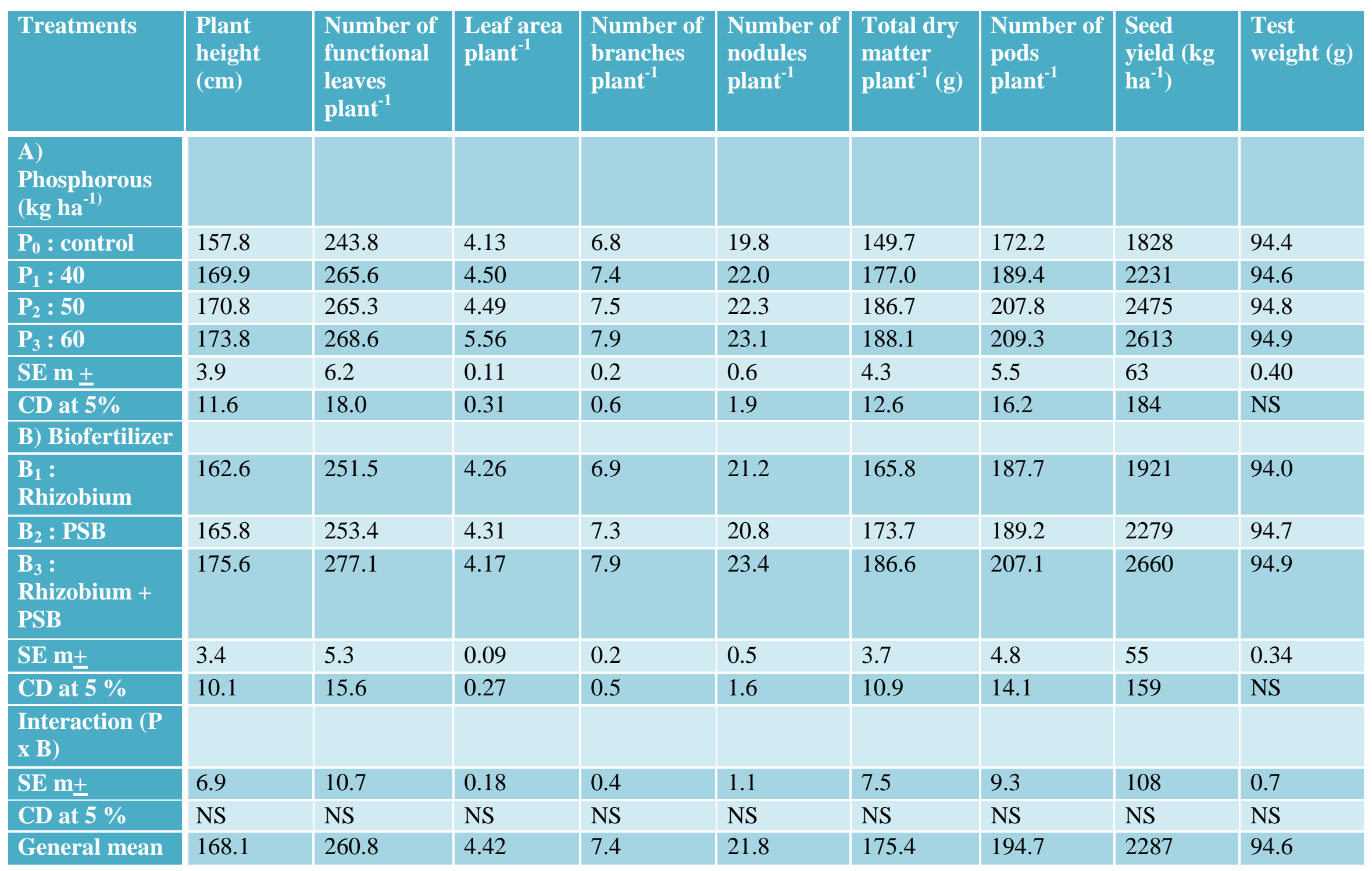


Table.2 Protein content, protein yield and economics of pigeonpea as influenced by Different levels of phosphorus and various liquid bio-fertilizers

\begin{tabular}{|c|c|c|c|c|c|}
\hline Treatments & $\begin{array}{c}\text { Protein } \\
\text { content } \\
(\%)\end{array}$ & $\begin{array}{l}\text { Protein yield } \\
\left(\mathrm{kg} \mathrm{ha}^{-1}\right)\end{array}$ & $\begin{array}{l}\text { GMR } \\
\left(\mathbf{h a}^{-1}\right)\end{array}$ & $\begin{array}{l}\text { NMR } \\
\left(\mathbf{h a}^{-1}\right)\end{array}$ & $\begin{array}{l}\text { B:C } \\
\text { Ratio }\end{array}$ \\
\hline \multicolumn{6}{|c|}{ A) Phosphorous $\left(\mathrm{kg} \mathrm{ha}^{-1)}\right.$} \\
\hline$P_{0}:$ control & 18.62 & 340 & 93751 & 59034 & 2.7 \\
\hline$P_{1}: 40$ & 18.75 & 419 & 114374 & 76407 & 3.0 \\
\hline$P_{2}: 50$ & 18.92 & 467 & 126895 & 88098 & 3.3 \\
\hline$P_{3}: 60$ & 19.32 & 505 & 133994 & 94405 & 3.4 \\
\hline $\mathrm{SE} \mathbf{m} \pm$ & 0.18 & 12 & 3177 & 3177 & - \\
\hline CD at $5 \%$ & NS & 34 & 9317 & 9317 & - \\
\hline \multicolumn{6}{|l|}{ B) Biofertilizer } \\
\hline $\mathbf{B}_{1}$ : Rhizobium & 18.66 & 357 & 98550 & 60796 & 2.6 \\
\hline $\mathbf{B}_{2}:$ PSB & 18.91 & 432 & 116858 & 79104 & 3.1 \\
\hline $\mathbf{B}_{3}$ :Rhizobium + PSB & 19.15 & 510 & 136353 & 98560 & 3.6 \\
\hline SE $\mathrm{m} \pm$ & 0.15 & 10 & 2751 & 2751 & - \\
\hline CD at $5 \%$ & NS & 30 & 8069 & 8069 & - \\
\hline \multicolumn{6}{|l|}{ Interaction (P x B) } \\
\hline SE $\mathrm{m} \pm$ & 0.30 & 20 & 5503 & 6276 & - \\
\hline CD at $5 \%$ & NS & NS & NS & NS & - \\
\hline General mean & 18.90 & 433 & 117254 & 79486 & 3.1 \\
\hline
\end{tabular}

Effect of phosphorus on quality and economics of pigeon pea

Higher protein content (19.32\%) with a protein yield (505 kg ha ${ }^{-1}$ ) was obtained by the application of $60 \mathrm{~kg} \mathrm{P}^{-1}$. While protein content did not differ significantly but protein yield found significantly higher with the application $60 \mathrm{~kg} \mathrm{P} \mathrm{ha}^{-1}$. The maximum gross momentary return ( $1,33,994 \mathrm{ha}^{-1}$ ) and net momentary return ( $94405 \mathrm{ha}^{-1}$ ) with higher $\mathrm{B}: \mathrm{C}$ ratio (3.4) recorded with $60 \mathrm{~kg} \mathrm{P}^{-1}$ and found significantly at par with $50 \mathrm{~kg} \mathrm{P} \mathrm{ha}{ }^{-1}$ (Table 2).

\section{Effect of bio-fertilizers on quality and economics}

Dual inoculation of liquid biofertilizers (rhizobium + PSB) was obtained higher protein content $(19.15 \%)$ in pigeon pea seed, protein yield $\left(510 \mathrm{~kg} \mathrm{ha}^{-1}\right)$ GMR ( 136353 $\mathrm{ha}^{-1}$ ) and NMR ( $98560 \mathrm{ha}^{-1}$ ) with the higher B: C ratio (3.4) was recorded with dual inoculation of liquid rhizobium and PSB culture.

The pigeon pea crop should be applied with $50 \mathrm{~kg}$ phosphorus $\mathrm{ha}^{-1}$ for better growth and higher yield.

To obtain higher gross and net momentary returns from pigeon pea crop apply $50 \mathrm{~kg}$ phosphorus ha ${ }^{-1}$ and rhizobium + PSB culture seed treatment.

\section{References}

Aher, S.H., Gokhle, D.N., Kadam, S.R. and Karnjikar, P.N. 2015. Effect of sources and level of phosphorous on yield, quality and phosphorous uptake in 
pigeonpea. Int. J. of Agril. Sci. 11:5962.

Ahmed, R., Solaiman, A.R.M., Halder, N.K., Siddiky, M.A. and Islam, M.S. 2007. Effect of inoculation methods of Rhizobium on yield attributes, yield and protein content in seed of pea. J. Soil. Nature 1 (3): 30-35.

Dalal, L. P. and Nandkar, P.B. 2010. Effect of NPK and biofertilizers on pigeonpea (Cajanus cajan L. Millsp.) Int. quarterly J. of Life. Sci. 5(1):171-172.

Deshbhratar, P.B., Singh, P.K., Jambhulka, A.P. and Ramteke, D.S. 2010. Effect of sulphur and phosphorous on yield, quality and nutrient status of pigeonpea (Cajanus cajan). J. Environ. Bio. 31(6):933-937.

Dutta and Bandopadhay, 2009. Performance of chickpea (Cicer arietinum L.) to application of phosphorus and biofertilizer in laterite soil. Archives of Agronomy and Soil Sci. Vol. 55, No. 2: 147-155.

Gaud, V.V. and Kale, H.B. 2010. Productivity and profitability of pigeonpea under different sources of nutrients in rainfed condition of central India $J$. of food Legumes. 23 (3\&4): 212-217.

Khan, V.M., Manohar, R.S., and Verma, H.P. 2015. Effect of vermicompost and biofertilizer on symbiotic efficiency and yield of cowpea in arid zone of
Rajasthan. Asian J. of Biosci. Vol. 10 (1): 113-115.

Kuamr Sandeep, Tomar Tejveer Singh, Tomar Savita and Singh Subey, 2015. Effect of phosphorus and biofertilizers in pigeonpea and its residual effect on the productivity of wheat under pigeonpea-wheat cropping system. Ann. Agric. New Series Vol. 36 (1) 38-43.

Kumar Avinash and Kushwaha, H.S. 2006. Response of pigeonpea (Cajanus cajan) to sources and level of phosphorus under rainfed condition. Indian $J$. of Agronomy. 51(1): 60-62.

Kumar Subhodh and Singh, B.P. 2014. Productivity and profitability of pigeonpea (Cajanus cajan L. Millsp.) genotypes as influenced by phosphorous and sulphur fertilization. J. Rural Agril. Res. 14 (1): 23-27.

Mahetele Devendra and Kushwaha, H.S. 2011. Productivity and profitability of pigeonpea as influenced by FYM, PSB and phosphorus fertilization under rainfed condition J. of Food Legumes. 24(1): $72-74$

Malik, Singh Jitendra Kumar, Thenua Ravindra, O.V.S. Kumar and Anil 2013. Response of pigeonpea (Cajanus cajan) + Mungbean (Phaseolu radiatus) intercropping system to phosphorus and biofertilizers. AGRIS 36(4): 323-330.

\section{How to cite this article:}

Ade, U.K., S.A. Bhusari, S.G Mane and Kalegore, N.K. 2018. Studies on Growth, Yield and Quality of Pigeon Pea (Cajanus cajan L. millsp.) as Influenced by Different Levels of Phosphorous and Liquid Biofertilizers. Int.J.Curr.Microbiol.App.Sci. 7(09): 2303-2307. doi: https://doi.org/10.20546/ijcmas.2018.709.285 